\title{
Utopia University: A Faculty Member Reflects on Recommendations for the Future of SoTL
}

\author{
Krista D. Forrest, PhD \\ Professor of Psychology \\ University of Nebraska at Kearney
}

I am fortunate. I work in a department where the scholarship of teaching and learning (SoTL) is actively pursued and has been for over 20 years. Colleagues have presented at several teaching conferences within the discipline of psychology, and many have published articles on subjects ranging from working with undergraduates in research partnerships to the effects of using different technologies in the classroom. In addition to departmental support, my small midwestern university's promotion and tenure policy has a statement that specifically recognizes peer-reviewed SoTL as counting toward promotion and tenure. This statement includes a web link to the first Carnegie Foundation for the Advancement of Teaching Report, Rethinking What it Means to be a Scholar (Rice, 1990).

This does not mean the fight for SoTL has ceased on my campus. As stated by Hutchings, Huber, and Ciccone (2011), sometimes the battle is not with the university, but with individual departments that hold onto the notion that only discipline specific scholarship is worthy of praise. Although I often encouraged faculty who developed new pedagogical techniques to write about these experiences and submit manuscripts to relevant teaching journals in their discipline, they often replied, "Why would I do that, it won't count?" and "It's not real scholarship." It appears the greater concern about the role of SoTL does not come from the university, or even the college, but often starts with each faculty member.

One of the highlights of Hutchings et al. (2011) is the authors' discussion of Utopia University. They describe a campus of the future where faculty members' SoTL has gone on to change departments and as the departments changed, so did the institution. The goal at Utopia $U$ is to assist students in becoming "expert learners" ( $p .113$ ). The University does this through first year seminars, capstone courses taken by juniors, and ongoing programs designed to help each student understand the learning process that best works for him or her. Faculty also strive to learn by conducting research in their own classes. These outcomes are then used in changing courses to best respond to current and even future students. Those same faculty feel encouraged to conduct this research because they know that, if published, it will count toward promotion and tenure. The administration at Utopia $\mathrm{U}$ is happy to financially support this work because they know that one way to guarantee the accreditation crucial to their existence is to have excellent, productive faculty who inspire their students to perform at their best.

Hutchings et al. (2011) go on to make several recommendations for institutions to follow if they want to integrate SoTL into their climates. The goal of

\footnotetext{
Note

2 To best understand my reflections, $I$ think it is important for the reader to consider my experience. I have 20 years of teaching experience, with 16 of those at my current university. Over the last 15 years I have published several articles in pedagogy. I have also served as the director of the Center for Teaching Excellence and developed several new programs designed to assist new and existing faculty in developing innovative courses. For me, as for many others, teaching is not just a job or career; it is my life.
} 
this paper is to respond to these suggestions for educating a new professoriate from the point of view of an educator, a SoTL researcher, and a former teaching center director.

\section{Understand, Communicate, and Promote an Integrated Vision of the Scholarship of Teaching and Learning.}

Hutchings et al. (2011) argue that the terminology, "scholarship of teaching and learning," can be its own nemesis. Faculty members disagree over whether research conducted in SoTL is rigorous enough, promotion and tenure committees disagree about its relevance, and administrators disagree over whether it should be funded. The authors go on to argue that knowing when to use the phrase and when to find alternative, acceptable ways of referring to the discipline can determine whether SoTL will be accepted on a campus. I would like to suggest that the issue may be less about the label SoTL and more about its implications.

In order to promote an intelligible vision of teaching and learning scholarship across a campus or campuses, one of the first things faculty need to do is overcome the fear of failure. Not every discipline specific brings its researcher a preferred outcome. When the findings are not significant or the outcome is counterintuitive to the hypothesis, most researchers reevaluate their work and conduct the research again using different variables, controls, or participants. Scholarship in teaching and learning is no different. Each time faculty members evaluate classroom teaching strategies, academic programs, or curricula, they run the risk of discovering that the techniques or courses they thought worked, that they love, do not contribute to student learning. Some of their beloved teaching techniques, assignments, lectures, and courses are not going to pass the test. Instead of seeing a negative outcome as an end-all failure, faculty need to use that opportunity to change what they do and how they do it. Finding out one technique does not work means there is an opening in the course to try something new. As a result, faculty members grow as instructors. It follows that academic majors or programs with such innovative teaching will become more popular with students. Perhaps the proposed confusion about terminology is less about the words and more about the possible consequences of researching and evaluating teaching.

At the programmatic level, institutions need to not only recognize discipline specific research in teaching and learning as scholarship, but also offer faculty the resources to make data-driven changes and the opportunity to share these experiences with others. There are many ways in which universities can support these types of endeavors.

\section{Support a Wide Range of Opportunities to Cultivate the Skills and Habits of Inquiry into Teaching and Learning.}

As suggested by Hutchings et al. (2011), colleges and universities should provide supportive climates that encourage faculty to engage in the scholarship of teaching and learning. Examples of supportive measures include funding for teaching-related expenses such as conferences, travel, and new materials.

Financial support is very beneficial to faculty, and one of the most efficient ways to use money targeted toward the scholarship and learning is through the development and maintenance of a teaching center. By having a teaching center for the entire campus, faculty regardless of discipline can have access to the resources they need to become better teachers. Whereas funding resources are helpful, access to knowledgeable others can be even more so. Teaching centers can provide faculty members with regular opportunities to interact and discuss teaching issues. If those opportunities are not available, teaching centers can create online discussion threads and repositories of campus-wide pedagogical initiatives so that faculty can see what kind of local energy is being devoted to teaching and learning. 
Teaching centers can also be integral in changing the campus climate concerning the scholarship of teaching and learning. Working with faculty in their first year is one of the fastest ways to change the acceptance of and expectation for SoTL. Have faculty who regularly publish in the area of teaching and learning share these experiences with new faculty (Richlin \& Cox, 2004). In my experience as a director, newer faculty are more likely to have come from graduate programs which include training in pedagogy; therefore, they tend to be more interested in acquiring new teaching skills. It is harder to convince seasoned faculty that examining teaching and learning issues is worthwhile, because many do not believe they have something new to learn. Yet even those who have been in the classroom for a long time can benefit from dialogue with faculty in their first five years of teaching. New faculty are often more educated in innovative pedagogical strategies, more current in technology, and more familiar with a systematic approach to examining their course strengths and weaknesses because of their recent experiences with pedagogical instruction. One way to encourage novice faculty and their experienced counterparts to talk about teaching is to set up mentoring pairs (McGrath, 2012; Richlin \& Cox, 2004; Trask, Marotz-Baden, Settles, Gentry, \& Berke, 2009). Experienced faculty share their knowledge of institutional history as well as their thoughts about teaching, and newer faculty ask their questions and share what teaching techniques they have learned.

Often missing from institutional support, regardless of the presence of a teaching center, is more time in our hectic schedules. This is why I like Hutchings' and colleagues' suggestion to transform the random teaching workshops into a systematic and integrated faculty-driven research program on teaching and learning. Most universities, like my own, already have a core group of faculty who are interested in or are currently conducting research in teaching issues. Although they are aware of each other, those faculty members may have no idea what their colleagues are currently studying or what issues interest them. Let universities offer faculty members course release time in return for completing a research commitment targeting a course, major, or program.

Another use of release time that could encourage SoTL to encourage faculty is to offer classes, workshops, and mentors in the statistical skills necessary to evaluate curriculum changes or encourage interdisciplinary authorships and publication so that authors' strengths can be recognized and strategies can be shared. According to Dawson, McLaughlin, Carson, and Zadnik (2012), one of the largest barriers to successful completion of such work is faculty members' difficulty in understanding research methodology outside of their specific field. Faculty could also take this time to participate in SoTL oriented certificate programs. One such program is housed at the University of British Columbia (Hubbell \& Burt, 2006). There, faculty can learn to define SoTL, conduct research in their area, disseminate their findings and evaluate other SoTL over the course of eight months. Regardless of the format, faculty would learn skills such as how to distinguish SoTL from simple course evaluation and understand the benchmarks associated with good statistical rigor in the field (Wilson-Doenges \& Gurung, 2013).

Regardless of the format, once faculty members complete their SoTL projects they can disseminate those findings to other constituencies on campus. If those outcomes are then presented at regional or national venues, the faculty member and campus benefit again. A university sponsored program such as this not only offers time to faculty researchers interested in teaching and learning issues, but also shows that this type of work is a recognized and valued contribution to student learning and success.

\section{Connect the Scholarship of Teaching and Learning to Larger, Shared Agendas for Student Learning and Success.}

One of the most interesting suggestions involves the connection of the scholarship of learning to student learning and success. Specifically, Hutchings et 
al. (2011) address how faculty can work together to build or renovate existing programs such as General Studies. Although a valid suggestion, faculty conducting SoTL can also work side by side with other existing departments whose objectives are to increase student success by cocreating new, innovative programming through their involvement with other departments (Schumann, Peters, \& Olsen, 2013). Examples from my university include Academic Success and Career Services, The Learning Commons, Disability Services, The First Year Program, etc. Goals for student performance are similar for a teaching center and other departments on campus. All want students to learn and professors to teach well. However, there is more to the collaboration than that. Both parties have information to share with each other. In turn, this faculty-staff collaboration makes each of the programs better (Schumann et al., 2013). Specific to my university are collaborations such as advising as teaching, using technology in the classroom, and flipped learning. None of these programs would have been possible if the teaching center had not partnered with other offices on campus. Because every interaction that a faculty or staff member has with a student is the opportunity for a teaching moment, faculty members engaging in pedagogical work and staff providing support services to students can learn from each other.

The student evaluation process for faculty is another place where SoTL has provided insight into student learning. Galbraith, Merrill, and Kline (2012) examined the teaching evaluations of 116 business classes. Three different analyses failed to demonstrate that student evaluations of teaching effectiveness (SETEs) directly related to teaching effectiveness or student learning. Perhaps in addition to evaluating faculty, students should also be encouraged to evaluate themselves and their accomplishments each semester. Our university's evaluation questions include the degree to which the instructor is stimulating, knowledgeable, enthusiastic, responsive, well-prepared, clear, fair, etc. Changing course evaluations from faculty-centered "what kind of person is he or she" to a studentcentered "here is what I learned" could better offer instructors, their department chairs, and other administrators a true gauge of the course's success. This additional evaluation could occur during the regular evaluation process of a course by adding these questions to the standard evaluation form or during academic advising. The latter could use the same form, but students would have a conversation with their faculty advisor concerning their courses and whether these courses meet their expectations. There are many ways to assess a course, and faculty members, departments, and other subdivisions can turn to the department of assessment for assistance with this process.

\section{Foster Exchange between the Campus Scholarship of Teaching and Learning Community and Those with Responsibility for Institutional Research and Assessment.}

Much dialogue can occur between those searching for teaching effectiveness in the classroom and their partners who evaluate some of the larger institutional goals. However, for both conceptual and practical reasons, avoid the trap of merging the scholarship of teaching and learning with assessment, as the two have different but equally important values. Hutchings and colleagues (2011) suggested instructors are often discovering and sharing with their colleagues what aspects of teaching and student learning do not work. In contrast, departments of assessment are often charged to show why the institution is deserving of accreditation. Many institutions see these ventures as identical and have responded by having the same individual, working half-time at each position, direct both positions. Because assessment is required for accreditation and the scholarship of teaching and learning is not, the latter program can often be overshadowed by the first. 
Even when programs are presented, the topics may lean toward handling assessment issues and not providing pedagogical information. When a Teaching/ Assessment center focuses primarily on assessment, faculty may interpret this bias as an unwritten message that the education and research associated with teaching as scholarly work is tolerated at best and unimportant or frowned upon at worst.

\section{Work Purposefully to Bring Faculty Roles and Rewards into Alignment with a View of Teaching as Scholarly Work.}

Many faculty conducting pedagogical research feel stranded on an island and even with a laptop and WiFi feel isolated nonetheless. When the professoriate still believes that scholarship in teaching and learning is either second-rate to subject research or not valued at all, instructors suffer. However, the students suffer the most. They continue to go to the same classes, read from the same books, and take the same exams (Hodges, 2013).

According to Hutchings et al. (2011), one of the best ways to bring faculty roles and rewards into alignment with teaching as scholarly work is to have a strong, viable Teaching Center on campus. As indicated earlier, teaching centers can be the hub of faculty interaction concerning teaching and learning issues. The ability for a professor to say, "I have a problem" and having fellow faculty offer solutions (rather than disdain) contributes greatly to the perception that it is "OK" to talk about teaching.

However, at a time when the scholarship and learning is receiving greater recognition as a discipline of its own and the faculty teaching load is increasing, many colleges and universities are either minimizing or closing their teaching centers (Glenn, 2009). Regardless of whether it is due to budgetary constraints or changes concerning the mission of the institution, this decision is often shortsighted. When faculty fail to evaluate their courses, programs, and curricula beyond the student evaluation and in turn, fail to respond to those evaluations by making changes, enrollment decreases. As a result, the institution stands to lose more money than it would have paid to support the teaching center program

From the perspective of a faculty member, for scholarly work in teaching and learning to increase, then it has to matter to someone other than him- or herself. The work has to matter in the researcher's department, and it has to matter at promotion and tenure time. However, scholarship in teaching and learning will not be counted towards productivity if faculty continue to view it as secondary to work in their own discipline. Colleges and universities can benefit by having faculty representatives travel to other universities or conferences where vibrant teaching and learning scholarship is the norm rather than the exception. Those institutions have already fought the battle of whether this type of research should count toward promotion and research, and how to so convince the campus constituencies.

\section{Take Advantage of and Engage with the Larger, Increasingly International Teaching Commons.}

Hutchings et al. (2011) suggest having faculty and administrators attend an international conference on teaching and learning, such as the one sponsored by the International Society of Teaching and Learning, in order to be part of a larger community. This suggestion is especially relevant for those faculty members from our "island." When an instructor sees him- or herself as the exception to the rule rather than the rule, an active program in teaching and learning scholarship can become harder to maintain. Having others with similar interests view one's work is a great motivator for continued performance. Also, conferences such as these can spark new ideas, research questions, and collaborations that not only benefit faculty members but also their institutions (MacKenzie \& Meyers, 2012). Administrators should attend so they can see the value of teaching and learning scholarship as well as have an idea of the breadth (and depth) of the discipline. Those new to the 
discipline should especially consider attending in order to best prepare for the development of a scholarship program such as this on their campus.

\section{Develop a Plan and Timeline for Integrating the Scholarship of Teaching and Learning into Campus Culture, and Monitor Process; and 8. Recognize that Institutionalization is a Long-Term Process.}

Once the general idea of doing research on teaching and learning has become accepted by a few members of a campus faculty, it becomes time to introduce the plan for integrating the idea into campus culture; however, those constituencies need to remind themselves that institutional change is slow. Two venues where the introduction may take place include the faculty governing body on campus such as the faculty senate, or the institution's teaching center. Faculty members can then work together to develop clear objectives for an eventual acceptance of the scholarship of teaching and learning (SoTL) and specific ways for interested faculty to meet those objectives. Of utmost importance is educating the administration of how SoTL will improve not only the curricula but also the institution itself (Hubball, Pearson, \& Clarke, 2013). At the same time, the campus proponents for the acceptance of SoTL as a discipline need to keep in mind that institutionalization is a slow process. I agree with the authors that a top-down approach would only be detrimental to a budding program. Faculty should begin the process, own it, and evaluate the products. However, even when it appears that SoTL has been accepted by the college or university, understand that there are still individuals who will not accept this discipline.

The recommendations proposed by Hutchings et al. (2011) do offer excellent suggestions for taking an existing SoTL program and making it better. Inherent in these recommendations is the assumption that some individuals on campus are doing work in SoTL and if enough faculty interested in the topic band together, they have the ability to change the campus, including institutional requirements for promotion and tenure. I think the information they provide might even assist that group of supporters in turning their campus into one that encourages SoTL. But the recommendations do not suggest what to do with the extreme naysayer and those scattered departments that refuse to accept SoTL as a valid field, even when their university does. Do these few barriers to Utopia University even matter? As long as these individuals or departments serve as the gatekeepers in charge of hiring new faculty (and not promoting or granting tenure to faculty within the department), Utopian University will always be 10 years down the road.

\section{References}

Dawson, V., McLaughlin, M., Carson, K. \& Zadnik, M. (2012). A pilot program to build research competence in teaching and learning in academics, In Proceedings of the Australian Conference on Science and Mathematics Education (formerly Uniserve Science Conference).
Gailbraith, C. S., Merrill, G. B., \& Kline, D. M. (2012). Are student evaluations of teaching effectiveness valid for measuring student learning outcomes in business- related classes? A neural network and Bayesian analyses. Research in Higher Education, 53, 353-374. 
Glenn, D. (2009, September 9). Wary of the budget knife, Teaching centers seek to sharpen their role. Chronicle of Higher Education, 56 (2).

Retrieved from http://0-

web.ebscohost.com. rosi.unk.edu/eho st/detail?sid=6a135a4a-76c2-418bb28b-

e77cbldd8b6a\%40sessionmgr4\&vid= $2 \&$ hid $=11 \&$ bdata $=$ J nNpdGU9ZWhvc3 QtbGI2ZSZzY29wZT1zaXRI\#db=aph\& $\mathrm{AN}=44294845$

Hodges, L. C. (2013). Postcards from the edge of SoTL: A view from faculty development. Teaching and Learning Inquiry, 1, 71-79. doi:

10.1353 /iss. 2013.0014

Hubball, H., Pearson, M. L., \& Clarke, A. C. (2013). SoTL inquiry in broader curricular and institutional contexts:

Theoretical underpinnings and emerging trends. Teaching and Learning Inquiry, 1, 41-57. doi: 10.1353 /iss. 2013.0009

Hutchings, P., Huber, M.T., \& Ciccone, A. (2011). The scholarship of teaching and learning reconsidered: Institutional integration and impact. San Francisco, CA: Jossey-Bass.

Mackenzie, J. \& Meyers, R. A. (2012). International collaboration in SoTL: Current status and future direction. International J ournal for the Scholarship of Teaching and Learning, 6 (1), Retrieved from http://eaglescholar.georgiasouthern. edu: $8080 /$ jspui/bitstream/10518/488 $3 / 1 / \mathrm{IJ}-$

SoTLv6n1_IE_MacKenzie $\% 20 \% 26 \% 2$ OMeyers.pdf
McGrath, A. (2012). An early introduction to SoTL and the shaping of an academic career. International Journal for the Scholarship of Teaching and Learning, 6 (2), Retrieved from http://eaglescholar.georgiasouthern. edu: $8080 / j$ spui/bitstream/10518/542 2/1/Personal\%20Reflection_McGrath. pdf

Rice, E. (1990, Winter-Spring). Rethinking what it means to be a scholar. In L. Ekroth (Ed.), Teaching Excellence: Toward the Best in the Academy. Stillwater, OK: POD Network.

Richland, L. \& Cox, M. D. (2004). Developing scholarly teaching and the scholarship of teaching and learning through faculty learning communities, New Directions for Teaching and Learning, 2004, 127135. doi: 10.1002/tl.139

Schumann, D. W., Peters, J., \& Olsen, T. (2013). Cocreating value in teaching and learning centers [Special Issue]. New Directions for Teaching and Learning, 2013, 21-32. doi: $10.1002 /$ tl.20043

Trask, B. S., Marotz-Baden, R., Settles, B., Gentry, D., \& Berke D. (2009). Enhancinggraduate education: Promoting a scholarship of teaching and learning through mentoring. International J ournal for the Scholarship of Teaching and Learning, 20 (3), Retrieved from http://www. isetl.org/ijtlhe/pdf/IJTLH E20\% 283\% 29.pdf\#page $=132$

Wilson-Doenges, G., \& Gurung, R. A. R. (2013). Benchmarks for scholarly investigations of teaching and learning. Australian J ournal of Psychology, 65, 63-70.

Krista D. Forrest is a professor of psychology at the University of Nebraska at Kearney. In addition to her work on jury deliberation and police interrogations, she has published more than 15 articles on pedagogy. 